\title{
PERBANDINGAN CERITA RAKYAT SASAK DAN SAMAWA: UPAYA MEMAHAMI MASYARAKAT SASAK DAN SAMAWA
}

\section{(THE COMPARATIVE STUDY ON SASAK AND SAMAWA FOLKTALES: UNDERSTANDING THE PEOPLE OF SASAK AND SAMAWA)}

\author{
Syaiful Bahri
}

\author{
Kantor Bahasa NTB, Jalan Dokter Sujono, Mataram, NTB \\ Ponsel: 08175725520, Posel: sbkailani@gmail.com
}

Diterima; 4 Oktober 2018; Direvisi: 15 Oktober 2018; Disetujui: 24 November 2018

\begin{abstract}
In this paper, there are two problems to be answered, namely are (1) the comparison between Sasak and Samawa folktales and (2) the description of Sasak and Samawa people based on the folktales. The folktales used as data are (1) Batu Goloq (Sasak) and Batu Plantolan (Samawa); Mandalika (Sasak) and Lala Buntar (Samawa); and (3) Tegodek dait Tetuntel (Sasak) and Ne Bote Ne Kakura (Samawa). Data are gathered through library research. Problems are answered using Levi-Strauss structural theory saying that tale is the gate of understanding the people. It is found that the relation of each group of tales shows a consistency in similarities and differences. Batu Goloq and Batu Plantolan give a description that Sasak people tend to solve problems by themselves as a consequence of being closed people, while Samawa people tend to invite others in solving their problems as a consequence of being opened people. The similar characters found in Mandalika and Lala Buntar specifically in miteme processing, in taking decision, and solving problems. Mandalika is characterized as a closed figure, while Lala Buntar is an opened one in deciding and solving the problems. The comparison between Tegodek dait Tetuntel and Ne Bote Ne Kakura shows that Sasak and Samawa people tend to protest any mistreatment from high class community toward a lower class community. It is the manifestation of the same view toward refusal and disagreement to the oppression done by high status people.
\end{abstract}

Key words: folktales, comparative, structural Levi-Strauss

\begin{abstract}
Abstrak
Artikel ini menjawab dua permasalahan, yakni (1) perbandingan antara cerita rakyat Sasak dan Samawa dan (2) konsep berpikir masyarakat Sasak dan Samawa berdasarkan perbandingan cerita rakyatnya. Cerita rakyat yang dijadikan data analisis adalah tiga pasang cerita yang memiliki kemiripan, yakni (1) Batu Goloq (Sasak) dan Batu Plantolan (Samawa), (2) Mandalika (Sasak) dan Lala Buntar (Samawa), (3) Tegodek dait Tetuntel (Sasak) dan Ne Bote Ne Kakura (Samawa). Data tersebut diperoleh melalui studi pustaka. Penganalisisan data menggunakan analisis struktural Levi-Strauss. Hasil analisis menunjukkan bahwa relasi cerita rakyat Sasak dan Samawa diperlihatkan dari adanya bagian pada masing-masing pasangan cerita yang menunjukkan persamaan dan perbedaan secara konsisten. Konsep berpikir masyarakat Sasak dan Samawa dalam pasangan cerita Batu Goloq dan Batu Plantolan memperlihatkan masyarakat Sasak cenderung menyelesaikan permasalahan sendiri sebagai wujud ketertutupan yang dioposisikan dengan masyarakat Samawa yang cenderung mengikutsertakan orang lain sebagai wujud keterbukaan. Hal yang sama juga terlihat pada pasangan cerita Mandalika dan Lala Buntar sebagai tokoh puteri raja, terutama dalam miteme proses pengambilan keputusan dan cara penyelesaian masalah. Konsep berpikir masyarakat Sasak dalam ceritaMandalika cenderung tertutup, sedangkan masyarakat Samawa dalam cerita Lala Buntar cenderung lebih terbuka dalam memutuskan dan menyelesaikan permasalahan yang dihadapi. Perbandingan antara cerita Tegodek dait Tetuntel dan Ne Bote Ne Kakura memperlihatkan konsep berpikir masyarakat Sasak dan Samawa yang memprotesketidakterimaan atau ketidaksetujuanpada penindasan masyarakat kelas atas terhadap masyarakat kelas bawah.
\end{abstract}

Kata kunci: cerita rakyat, perbandingan, struktural Levi-Strauss 


\section{Pendahuluan}

Keberadaan Sasak dan Samawa tidak bisa dilepaskan dari hubungan keduanya yang telah lama terjalin. Secara geografis Sasak dan Samawa berada pada pulau yang berbeda, tetapi sejarah dan beberapa hasil kajian menyebutkan bahwa kedua suku ini memiliki hubungan yang lebih dekat dibandingkan suku lainnya di NTB. Ketika masyarakat Sasak melakukan perlawanan terhadap invasi Karangasem (Bali), masyarakat Samawa melalui Kerajaan Sumbawa mengirimkan pasukan untuk memberikan bantuan dengan melakukan penyeberangan ke Lombok. (Burhanudin, 2010; Mantja, 2011; Wacana, 1988). Keberadaan mereka dibuktikan dengan banyaknya perkampungan Samawa di Lombok yang bisa ditemukan hingga sekarang ini. Beberapa sumber juga menyebutkan bahwa Lombok dan Sumbawa pernah berada dalam satu pusat pemerintahan (Mantja, 2011; Wacana, 1988; Burhanudin, 2010).

Jauh sebelum terjalinnya hubungan yang dilatarbelakangi invasi Karangasem terhadap Lombok, Sasak dan Samawa pada dasarnya merupakan satu kesatuan. Kedua suku ini berasal dari satu nenek moyang yang sama. Simpulan seperti itu didapatkan dari hasil kajian rekonstruksi bahasa yang memperlihatkan bahwa bahasa Sasak dan Samawa merupakan dua bahasa yang termasuk dalam satu subkelompok bahasa
Sasak-Samawa. Subkelompok tersebut diturunkan dari satu bahasa proto, yakni protobahasa Bali-Sasak-Samawa. Protobahasa tersebut awalnya terpecah menjadi dua kelompok, yakni bahasa Bali dan bahasa Sasak-Samawa. Kelompok bahasa Sasak-Samawa inilah yang kemudian terpecah menjadi bahasa sendiri, yakni bahasa Sasak dan bahasa Samawa sebagaimana yang dikenal sekarang ini (Mbete, 1990).

Hubungan antara Sasak dan Samawa juga terekam dalam cerita rakyat. Cerita rakyat Sasak, Datu Langko, menggambarkan bahwa salah satu putra bangsawan Kerajaan Selaparang yang bernama Pangeran Panji Tilar Negara dititipkan di Sumbawa. Penitipan seorang pangeran kerajaan ini menjadi salah satu indikasi bahwa Sasak dan Samawa memiliki hubungan dekat, baik secara kelembagaan maupun secara emosional.

Kedekatan hubungan antara Sasak dan Samawa dengan berbagai bukti di atas menunjukkan bahwa intensitas interaksi kedua suku tersebut sangat besar. Besarnya interaksi akan berimplikasi pada adanya berbagai macam kesamaan, salah satunya adalah kesamaan cerita rakyat. Berkaitan adanya persamaan atau kemiripan cerita rakyat, ada dua pendapat besar yang menunjukkan perbedaan. Pendapat pertama menyatakan persamaan atau kemiripan cerita rakyat disebabkan karena adanya 
interaksi yang berkaitan dengan pengaruhmemengaruhi antara satu masyarakat pemilik cerita dengan masyarakat pemilik cerita yang lain. Pendapat kedua menyatakan bahwa kesamaan yang terjadi dalam cerita rakyat hanya bersifat kebetulan (lihat Ahimsa-Putra, 2013; Taum, 2011).

Terlepas dari adanya dua pandangan yang berseberangan tersebut, cerita rakyat merupakan salah satu jenis karya sastra yang bersifat anonim. Keberadaannya yang anonim dikatakan sebagai milik kolektif masyarakat. Sebagai karya sastra milik kolektif masyarakat, secara otomatis cerita rakyat mengungkapkan kesadaran kolektif masyarakat pemiliknya (Taum, 2011: 11). Oleh karena itu, menjadi hal yang wajar jika pengkajian terhadap cerita rakyat bisa dijadikan sebagai "pintu masuk" untuk memahami masyarakat pemilik cerita. Ahimsa-Putra (2013) menyatakan bahwa keinginan-keinginan yang tidak tertuangkan dalam dunia nyata, secara sadar atau tidak, tertuang dalam cerita rakyat. Hal itu dikarenakan segala peristiwa yang ingin diungkapkan dalam cerita rakyat tidak terikat oleh aturan atau nilai yang berlaku dalam dunia nyata.

Apabila kajian terhadap cerita rakyat dilakukan untuk memahami masyarakat pemilik cerita, membandingkan cerita rakyat dari dua masyarakat yang berbeda secara otomatis bisa dilakukan untuk membandingkan masyarakat pemilik cerita. Dengan kata lain, melihat relasi dengan membandingkan cerita rakyat Sasak dan Samawa secara otomatis bisa dijadikan dasar untuk membandingkan masyarakat Sasak dan Samawa sebagai pemilik cerita. Perbandingan bisa diarahkan untuk memahami masyarakat Sasak dan Samawa sebagai masyarakat yang berasal dari satu nenek moyang yang sama.

Berdasarkan pemikiran tersebut, artikel ini bermaksud membandingkan cerita rakyat Sasak dan Samawa. Perbandingan tersebut dilakukan dengan melihat bagian-bagian yang menunjukkan perbedaan dan persamaan dalam tiga pasang cerita rakyat yang memiliki kemiripan, yakni 1) Batu Goloq (Sasak) dan Batu Plantolan (Samawa), 2) Mandalika (Sasak) dan Lala Buntar (Samawa), serta 3) Tegodek dait Tetuntel (Sasak) dan Ne Bote Ne Kakura (Samawa). Tiga pasang cerita rakyat yang didapatkan dari penelitian Bahri dkk. (2015) tersebut akan dibandingkan dengan menggunakan teori strukuralisme Levi-Strauss. Penggunaan teori ini sangat penting karena sejalan dengan pandangan bahwa cerita rakyat bisa digunakan untuk memahami masyarakat pemilik cerita. Perbedaan dan persamaan yang terdapat dalam pasangan cerita rakyat akan diarahkan pada upaya 
memahami masyarakat Sasak dan Samawa sebagai masyarakat yang berasal dari satu nenek moyang. Bagian-bagian yang menunjukkan perbedaan akan dijadikan sebagai dasar memahami perbedaan mendasar dari kedua masyarakat pemilik cerita.

\section{Kerangka Teori}

Beberapa ahli menyatakan bahwa membandingkan karya sastra harus berpedoman pada prinsip menemukan adanya saling pengaruh yang mengarah pada upaya mencari orisinalitas sebuah karya sastra. Berkaitan dengan tujuan tersebut Endraswara (2011: 29) menyatakan tidak menutup kemungkinan adanya prinsip lain. Bandingan sastra tidak bisa secara keseluruhan dipaksakan pada upaya mencari orisinalitas, terlebih cerita rakyat yang penyebarannya secara lisan.

Berkaitan dengan upaya melakukan perbandingancerita rakyat, Damono (2009: 31) memberikan penjelasan bahwa membandingkan dongeng atau cerita rakyat yang memiliki kemiripan satu sama lain tidaklah bertujuan untuk menemukan yang asli atau menelusuri yang mempengaruhi dan dipengaruhi. Menelusuri cerita rakyat guna melihat perbedaan dan persamaan yang diarahkan pada upaya menelusuri saling pengaruh dikatakan akan sampai pada simpulan yang kurang meyakinkan. Hal yang bisa dilakukan adalah menunjukkan persamaan dan perbedaan yang ada, dan setelah itu-kalau memungkinkan — apa yang ada di balik itu semua. Salah satu yang bisa dilakukan adalah membandingkan cerita rakyat dengan tujuan melihat keterkaitan sekaligus perbedaan dan persamaan. Upaya tersebut pada tahap selanjutnya bisa diarahkan untuk melihat cerminan watak masyarakat.

Berpijak pada pendapat yang dikemukakan Damono, artikel ini menggunakan teori strukturalisme LeviStrauss sebagai teori untuk menganaliasis cerita rakyat dari dua etnis yang berbeda, yakni Sasak dan Samawa. Mengkaji karya sastra, termasuk cerita, dengan menggunakan teori Levi-Strauss secara otomatis merupakan kajian interdisipliner (Rokhman, 2003). Dikatakan demikian karena hakikat penggunaan teori LeviStrauss adalah menemukan logika berpikir masyarakat pemilik cerita. Oleh karena itu, melihat relasi cerita rakyat dengan cara melakukan perbandingan menggunakan teori Levi-Strauss secara otomatis akan membandingkan masyarakat pemilik cerita sebagaimana dilakukan dalam artikel ini.

Levi-Strauss (Ahimsa-Putra, 2013: 186) memandang cerita rakyat sebagai ungkapan simbolis dari konflik batiniah yang ada dalam suatu masyarakat. Dengan kata lain, cerita rakyat atau mitos merupakan sarana untuk mengelakkan, memindahkan, dan mengatasi kontradiksi- 
kontradiksi empiris yang tak terpecahkan.

Dalam cerita rakyat tergambar keinginankeinginan yang tidak mungkin tertuangkan dalam dunia nyata. Keinginan-keinginan tersebut tersusun atas sruktur-struktur sebagai sebuah mekanisme nalar, human mind. Meskipun demikian, keinginan maupun mekanisme cara bekerja nalar tersebut tidak disampaikan secara langsung dalam cerita. Dalam interpretasinya, LeviStrauss memperlihat-kan bahwa mitos terdiri dari (1) relasi-relasi serta oposisioposisi dan relasi-relasi, dan (2) dengan cara itulah pemikiran primitif (savage mind) berhasil menciptakan orde/ keteraturan dalam dunianya (Taum, 2011: 171).

Levi-Strauss (Ahimsa-Putra, 2003) membagi struktur narasi menjadi dua bagian, yakni struktur luar (surface strukture) dan struktur dalam (deep structure). Struktur luar adalah relasi-relasi antarunsur yang dapat kita buat atau bangun berdasarkan ciri-ciri luar atau ciri-ciri empiris dari relasi-relasi tersebut. Sementara itu, struktur dalam adalah susunan tertentu yang dibangun berdasarkan struktur lahir yang telah berhasil kita buat, tetapi tidak selalu terlihat pada sisi empiris dari fenomena yang kita pelajari. Struktur dalam ini dapat disusun dengan menganalisis dan membandingkan berbagai struktur luar yang berhasil ditemukan atau dibangun.
Struktur dalam inilah yang bisa dipakai untuk memahami fenomena (dalam hal ini narasi) yang diteliti karena melalui struktur inilah peneliti kemudian memahami berbagai fenomena yang dipelajarainya.

Relasi-relasi yang ada pada struktur dalam dapat diperas atau disederhanakan menjadi oposisi berpasangan (binary opposition). Oposisi biner adalah aspek paling penting yang bisa menyingkap bagaimana manusia berpikir, bagaimana manusia memproduksi makna dan memahami realitas. Oposisi biner dalam narasi bisa mengungkap makna di balik suatu cerita, logika di balik cerita. Analisis struktural dan menemukan oposisi biner berguna dalam memberikan petunjuk atas bekerjanya human mind atau nalar manusia, bagaimana nalar manusia bekerja. Dalam konteks naratif, ini terutama bisa menyingkap bagaimana logika di balik dibuatnya sebuah narasi (Eriyanto, 2013).

Analisis strukturalisme Levi-Strauss menetapkan tiga landasan analisis struktural terhadap mitos. (1) Jika mitos dipandang sebagai sesuatu yang bermakna, maka maknanya tidak terdapat pada unsurunsurnya yang berdiri sendiri, yang terpisah satu sama lain, melainkan pada kombinasi unsur-unsur tersebut. (2) Sekalipun mitos termasuk dalam kategori 'bahasa', bahasa mitos bukan sekadar bahasa biasa. Bahasa mitos memiliki ciri-ciri yang berbeda. Jika bahasa memiliki tiga tahap, yaitu fonem, 
kata, dan kalimat, maka mitos hanya mempunyai dua tahap, yaitu kata dan kalimat, sementara musik hanya memiliki dua tahap, yaitu nada dan kalimat musikal. (3) Ciri-ciri ini bersifat kompleks dan lebih rumit daripada ciri-ciri bahasa sehingga dapat kita temukan pada tingkat di atas bahasa. (Ahimsa-Putra, 2013: 93-94)

Penganalisisan dongeng atau cerita dengan menggunakan analisis strukural Levi-Strauss dilakukan dengan tiga langkah utama secara berurutan, yakni (1) mencari miteme (myteme); (2) mencari relasi di antara miteme-miteme yang telah ditemukan; dan (3) menyusun mitememiteme secara sintagmatik dan paradigmatik (Eriyanto, 2013: 171-172). Langkah-langkah ini akansampai pada tujuan akhir, yakni menemukan logika berpikir masyarakat pemilik cerita. Membandingkan tiga pasang cerita rakyat Sasak dan Samawa akan mengarah pada penemuan logika berpikir masyarakat Sasak dan Samawa dalam cerita rakyat yang berpasangan tersebut.

\section{Metode Penelitian}

Artikel ini menggunakan tiga pasang cerita pasang cerita rakyatSasak dan Samawa yang memiliki kemiripan sebagai data. Ketiga pasang cerita rakyat yang dimaksud, yakni (1) Batu Goloq dan Batu Plantolan, (2) Mandalika dan Lala Buntar, dan (3) Tegodek dait Tetuntel dan Ne Bote
Ne Kakura. Data tersebut diperoleh dari hasil inventarisasi cerita rakyat Sasak dan Samawa yang dilakukan Bahri dkk. (2015). Dengan demikian, pencarian data dilakukan dengan studi atau telaah pustaka yang oleh Sugiono (2008: 240) dikatakan sebagai studi dokumen.

Studi dokumen dilakukan selain untuk menemukan data cerita rakyat yang dianalisis, juga untuk menemukan datadata pendukung sebagai penguat tafsiran dari hasil analisis terhadap pasangan cerita yang dilakukan. Hal ini sejalan dengan prinsip analisis struktural Levi-Strauss yang menggunakan data kehidupan sosial budaya masyarakat sebagai bahan untuk menguatkan tafsiran terhadap analisis struktural cerita rakyat.

Data berupa tiga pasang cerita rakyat Sasak dan Samawa selanjutnya dianalisismenggunakan metode analisis struktural Levi-Strauss. Sebagaimana telah dipaparkan sebelumnya, penggunaan metode analisis struktural Levi-Strauss pada dasarnya bertujuan menemukan logika nalar masyarakat pemilik mitos atau cerita, yakni masyarakat Sasak dan Samawa. Langkah-langkah yang diterapkan dalam analisis data sebagai berikut.

1. Menentukan miteme dari masingmasing cerita, baik cerita rakyat Sasak maupun cerita rakyat Samawa. 
2. Miteme dari masing-masing cerita rakyat kemudian disusun secara sintagmatik maupun paradigmatik guna melihat keterhubungan dari miteme-miteme tersebut dalam konteks keseluruhan bagian dalam cerita.

3. Membandingkan susunan miteme antara cerita rakyat Sasak maupun Samawa guna menemukan letak perbedaannya.

4. Perbedaan-perbedaan dalam tataran miteme tersebut selanjutnya dijadikan dasar untuk menafsirkan perbedaan nalar atau cara pandang masyarakat Sasak dan Samawa terhadap sebuah permasalahan.

\section{Pembahasan}

\subsection{Perbandingan Cerita Rakyat Sasak dan Samawa}

Melakukan perbandingan terhadap cerita, termasuk cerita rakyat, tentunya harus diawali dengan memahami secara mendalam cerita rakyat yang akan dianalisis. Kegiatan memahami cerita rakyat dapat dilakukan dengan melihat rangkaian peristiwa yang dilakukan tokohtokoh hingga membentuk sebuah rangkaian cerita utuh. Hal ini sejalan dengan konsep dasar kajian struktur yang memandang sebuah cerita terdiri atas unsur-unsur, tetapi makna atau maksud akan tergambar dari rangkaian unsur secara keseluruhan.

\subsubsection{Perbandingan Cerita Batu Goloq dan Batu Plantolan \\ Perbandingan cerita Batu Goloq dan}

Batu Plantolan berkaitan dengan upaya menemukan persamaan dan perbedaan yang terdapat dalam kedua cerita. Persamaan dan perbedaan diidentifikasi dengan melakukan perbandingan rangkaian peristiwa dari awal hingga akhir cerita. Identifikasi persamaan maupun perbedaan kedua cerita ini dilakukan dengan mengelompokkan menjadi tiga bagian yang merupakan miteme cerita, yakni (1) latar belakang kehidupan, (2) permasalahan yang dihadapi, dan (2) cara menyelesaikan masalah.

Latar belakang kehidupan berkaitan dengan kondisi perekonomian yang terdapat pada kedua cerita. Tokoh Inaq Lembain dan Amaq Lembain dalam cerita Batu Goloq berada dalam kondisi yang serba kekurangan. Suami istri ini setiap hari berjuang untuk memenuhi kebutuhan sehari-hari. Inaq Lembain bekerja sebagai buruh penumbuk pada, sedangkan Amaq Lembain sebagai pencari kayu bakar di hutan. Hasil dari dua pekerjaan ini tentu sangat tidak menentu yang berimplikasi pada ketidakmenentuan mendapatkan makanan setiap harinya. Ketika pada hari tertentu bisa mendapatkan hasil dari pekerjaannya maka pada hari itu mereka bisa makan. Akan tetapi, pada hari lain hasil dari pekerjaan tidak didapatkan, 
mereka pun tidak makan pada hari itu. Tokoh suami istri yang sama-sama berjuang memenuhi kebutuhan sehari-hari pada tempat yang berbeda inilah yang menjadikan mereka harus mengikutsertakan anaknya dalam bekerja. Pada situasi seperti ini, tokoh Inaq Lembain sebagai ibu yang diserahi tugas untuk mengasuh anak sambil bekerja. Tuntutan mendesak untuk memenuhi kebutuhan sehari-hari menjadikan Inaq Lembain tidak memiliki pilihan lain selain membawa anaknya dalam bekerja.

Berbeda dengan tokoh Inaq Lembain dan Amaq Lembain, tokoh Ibu dengan nama yang tidak disebutkan secara terang dalam cerita Batu Plantolan memiliki kehidupan yang lebih baik.Bersama suaminya, tokoh $\mathrm{Ibu}$ memiliki pekerjaan dengan hasil yang lebih pasti. Mereka berdua secara bersama-sama berladang dengan tanah garapan sendiri. Dengan demikian, hasil yang didapatkan tentu lebih banyak sehingga pemenuhan kebutuhan sehari-hari tidak menjadi permasalahan bagi keluarga ini. Meskipun demikian, tokoh $I b u$ dalam cerita ini juga membawa anaknya dalam mengerjakan ladang garapannya. Dibawanya sang anak disebabkan ketidakadaan tokoh suami yang telah meninggal.

Miteme "permasalahan yang dihadapi" pada kedua cerita memiliki persamaan. Tokoh Inaq Lembain dalam cerita Batu Goloq memiliki maupun tokoh Ibu dalam cerita Batu Plantolan sama-sama membawa anaknya pergi bekerja. Alasan mengikutsertakan anak juga memiliki persamaan, yakni ketidakadaan orang yang akan menemaninya di rumah. Persamaan juga terdapat pada lokasi yang dipilih sebagai tempat sang anak menunggu sang ibu bekerja. Persamaan tersebut berlanjut sampai meningginya batu yang digunakan sebagai tempat sang anak menunggu ibunya yang sedang berkerja. Keberadaan sang anak di atas batu meninggi itulah yang sama-sama menjadi puncak permasalahan yang dihadapi oleh tokoh Inaq Lembain dalam cerita Batu Goloq maupun tokoh Ibu dalam cerita Batu Plantolan.

Perbedaan kembali terlihat pada miteme "cara menyelesaikan masalah". Tokoh Inaq Lembain menyelesaikan permasalahan (menurunkan sang anak) secara sendiri, yakni menggunakan peralatan berupa sabuk yang terikat di pinggang. Sementara itu, tokoh $\mathrm{Ibu}$ dalam cerita Batu Plantolan meminta bantuan tokoh lain berupa burung untuk membantu menurunkan sang anak. Pada bagian akhir miteme ini terlihat perbedaan yang menunjukkan bahwa anak dalam cerita Batu Goloq berubah menjadi burung, sedangkan anak dalam cerita Batu Plantolan tetap menjadi sosok anak yang kembali kepada orang tuanya. Perbandingan berupa persamaan dan 
perbedaan tersebut telihat dalam bagan berikut.

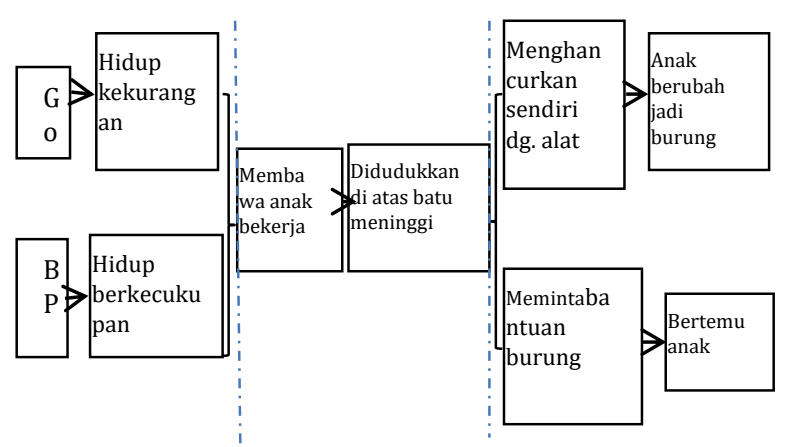

\subsubsection{Perbandingan Cerita Mandalika} dan Lala Buntar

Sebagaimana pasangan cerita sebelumnya, cerita Mandalika dan Lala Buntar terdiri atas tiga miteme, yakni (1) latar belakang tokoh, (2) permasalahan yang dihadapi, dan (3) cara mengatasi masalah. Persamaan terlihat pada dua miteme pertama, sedangkan perbedaan hanya terdapat pada miteme "cara mengatasi masalah". Miteme "latar belakang tokoh" berkaitan dengan latar belakang kehidupan tokoh yang terdapat pada masing-masing cerita. Tokoh Mandalika maupun Lala Buntar merupakan dua tokoh yang sama-sama sebagai putri raja. Kedua tokoh pada kedua cerita ini juga berada pada lingkungan istana dengan segala fasilitas yang tersedia.

Persamaan yang terdapat pada miteme "latar belakang tokoh" dilanjutkan dengan "permasalahan yang dihadapi". Mandalika maupun Lala Buntar samasama digambarkan sebagai putri raja yang cantik jelita. Kecantikan itulah yang mendorong banyak raja maupun pangeran kerajaan lainnya untuk datang melamar. Kedua cerita juga sama-sama menceritakan bahwa lamaran tersebut datang secara bersamaan dan masing-masing menuntut agar lamarannya diterima.

Tuntutan masing-masing pelamar agar diterima itulah yang menjadi permasalahan. Mandalika maupun Lala Buntar menyadari bahwa menerima salah satu pelamar akan menimbulkan pertikaian. Kedua putri ini sama-sama tidak menginginkan terjadinya pertikaian sehingga masing-masing memiliki cara agar pertikaian itu tidak terjadi.

Sebagaimana bagian yang menunjukkan perbedaan pada pasangan cerita sebelumnya, perbedaan pada pasangan cerita Mandalika dan Lala Buntar juga terdapat pada miteme "cara menyelesaikan masalah". Kebebasan mengambil keputusan untuk memilih yang diberikan orang tua telah mendorong Mandalika untuk meminta waktu menyendiri dan berpikir, sedangkan tokoh Lala Buntar langsung memutuskan untuk pergi meninggalkan istana dan bersembunyi di tengah hutan. Dua keputusan berbeda ini memperlihatkan bahwa tokoh Mandalika memilih mengetahui sendiri keputusan yang diambil, tanpa menginformasikan kepada tokoh lain, termasuk orang tua dan 
keluarga. Sebaliknya, tokoh Lala Buntar memberitahukan keputusan yang diambilnya kepada orang tua dan semua anggota keluarganya. Berdasarkan pemaparan tersebut, perbandingan berupa persamaan dan perbedaan dalam pasangan cerita tersebut dapat dilihat dalam bagan berikut.

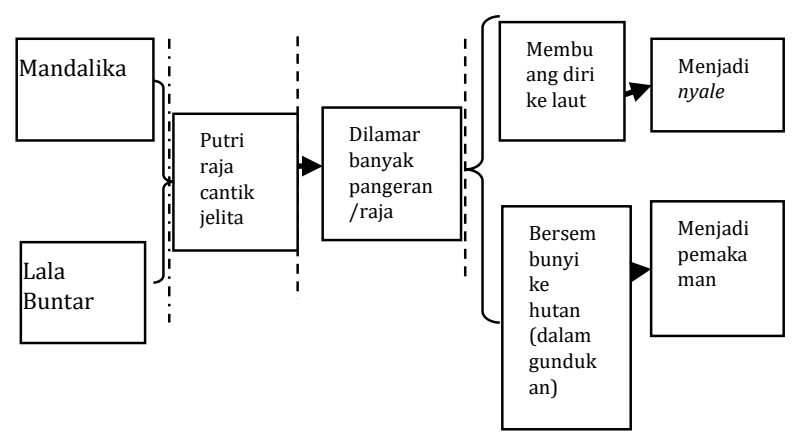

\subsubsection{Perbandingan Cerita Tegodek}

dait Tetuntel dan $\mathrm{Ne}$ Bote Ne Kakura

Relasi pada pasangan cerita ini memiliki perbedaan dibandingkan dengan dua pasangan cerita lainnya. Rangkaian peristiwa dari awal hingga akhir cerita memiliki persamaan. Perbedaan hanya terdapat pada tokoh protagonis yang menemani tokoh monyet sebagai tokoh antagonis. Pada cerita Tegodek dait Tetuntel, tokoh protagonis adalah kodok/katak, sedangkan pada cerita $\mathrm{Ne}$ Bote Ne Kakura yang menjadi tokoh protagonis adalah kurakura. Meskipun demikian, permasalahan dan rangkaian peristiwa yang dialami oleh tokoh kodok/katak sama persis dengan yang dialami oleh tokoh kurakura.
Permasalahan dan rangkaian peristiwa yang persis sama pada pasangan cerita Tegodek dait Tetuntel dan Ne Bote Ne Kakura menjadikan ketidakmungkinan untuk dibandingkan dengan model perbandingan sebagaimana dua pasangan cerita sebelumnya. Persamaan keduanya yang sama persis merupakan satu kesatuan. Perbandingan dengan melihat persamaan dan perbedaan lebih diarahkan pada upaya membandingkan dua tokoh protagonis dan antagonis yang berada pada posisi yang konsisten dari awal hingga akhir cerita. Hasil perbandingan tersebut terlihat pada bagan berikut.

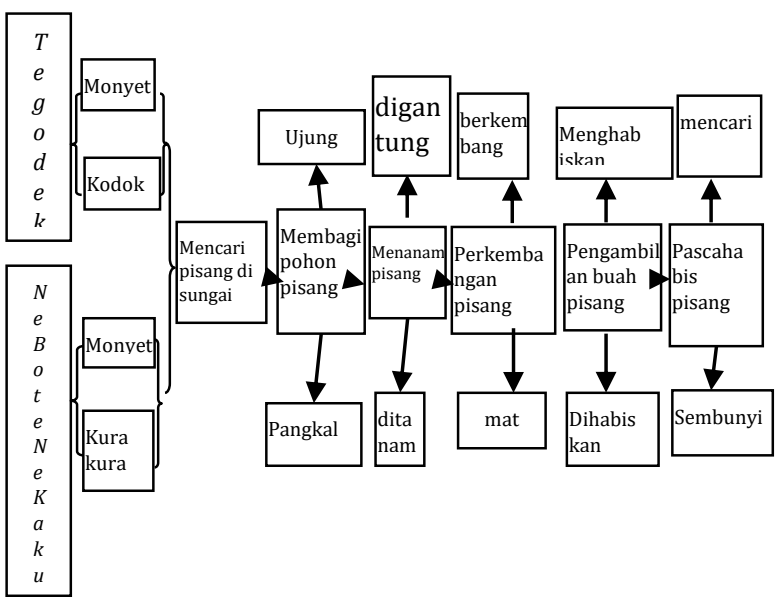

Bagan di atas memperlihatkan adanya beberapa miteme, yakni pembagian pohon pisang, (2) penanaman pisang, (3) perkembangan pisang, (4) pengambilan pisang, dan (5) pascahabis pisang. Masing-masing miteme tersebut secara konsisiten memperlihatkan posisi monyet yang berada atau memilih posisi pada bagian atas dibandingkan dengan 
kodok maupun kurakura yang mengambil posisi pada bagian bawah.

Miteme "pembagian pohon pisang" memperlihatkan bahwa tokoh monyet mengambil bagian atas dari pohon pisang yang dibagikan. Pengambilan bagian atas tersebut dilakukan dengan alasan agar cepat berbuah. Bagian bawah pohon pisang menjadi bagian kodok/katak maupun kurakura.

Tokoh monyet pada miteme "penanaman pisang" melakukan penanaman pisang dengan menggantung bagiannya pada dahan pohon asam yang posisinya paling tinggi. Berbeda dengan monyet, tokoh katak maupun kurakura memilih tanah sebagai tempat menanam bagian pisang yang didapatkan. Posisi seperti ini berlangsung dengan konsisten sampai akhir cerita, yakni pada miteme "pascahabis pisang".

\subsection{Konsep Berpikir Masyarakat Sasak dan Samawa dalam Cerita Rakyat}

Perbandingan dengan melihat persamaan dan perbedaan pada masingmasing pasangan cerita merupakan data awal yang dijadikan sebagai data untuk melihat konsep berpikir masyarakat Sasak dan Samawa sebagai pemilik cerita yang dibandingkan. Hal ini sejalan dengan prinsip kajian strukturalisme Levi-Strauss yang memandang cerita rakyat sebagai "pintu masuk" untuk memahami masyarakat pemilik cerita. Pemahaman terhadap masyarakat pemilik cerita ini lebih banyak difokuskan pada perbedaanperbedaan yang terdapat di dalamnya. Meskipun demikian, persamaan-persamaan yang terdapat di dalamnya juga menjadi perhatian guna melihat konteks keseluruhan sebagai struktur cerita.

Memahami tokoh Inaq Lembain dalam cerita Batu Goloq maupun tokoh ibu dalam cerita Batu Plantolan harus dilakukan dengan melihat cerita secara keseluruhan. Melakukan pemahaman terhadap solusi yang dipilih oleh tokoh Inaq Lembain maupun tokoh ibu harus dihubungkan dengan latar belakang kehidupan masing-masing tokoh. Latar belakang kehidupan yang dimaksud harus dihubungkan dengan latar belakang sebagaimana yang digambarkan dalam miteme sebelumnya, yakni miteme latar belakang kehidupan perekonomian masingmasing tokoh. Cara penyelesaian masalah yang dipilih oleh tokoh Inaq Lembain dalam Batu Goloq harus dihubungkan dengan kehidupan perekonomiannya yang penuh kekurangan dan kemiskinan. Begitu pula dengan cara penyelesaian yang dipilih oleh tokoh $i b u$ dalam cerita Batu Plantolan yang harus dihubungkan dengan kehidupan perekonomiannya yang masuk dalam kategori "berada". Dua hal ini saling mendukung dan memiliki keterkaitan satu sama lain. Solusi yang dipilih oleh masingmasing tokoh memiliki hubungan dengan 
kehidupan perekonomiannya. Sebaliknya, kehidupan perekonomian memiliki pengaruh terhadap solusi yang dipilih oleh masing-masing tokoh dalam memecahkan masalah yang dihadapinya.

Inaq Lembain sebagai tokoh yang kehidupannya berada dalam kategori miskin memilih menggunakan peralatan yang ada pada dirinya dan melakukan usaha secara sendiri untuk memecahkan permasalahan yang dihadapi. Tidak demikian dengan tokoh $i b u$ yang berada dalam kehidupan "berada". Tokoh ini menyelesaikan permasalahannya dengan meminta bantuan kepada orang maupun tokoh lain yang ada dalam cerita. Korelasi antara kondisi kehidupan perekonomian dengan cara penyelesaian masalah dalam kedua cerita rakyat yang dioposisikan tergambar dalam bagan berikut.

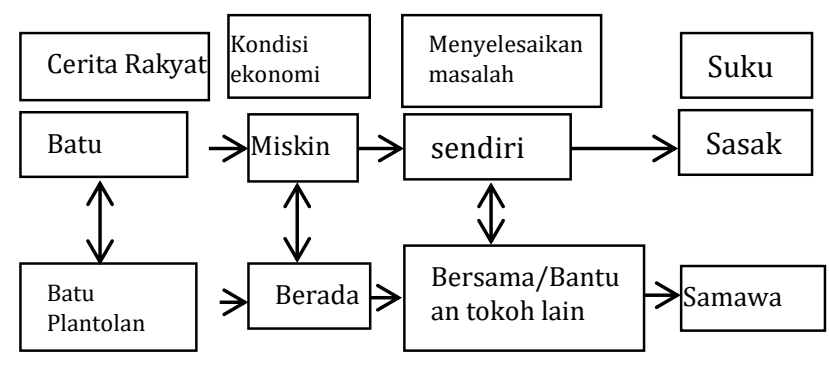

Konteks cerita Batu Goloq dan Batu

Plantolan dengan berbagai macam oposisi sebagaimana telah dipaparkan merupakan gambaran adanya oposisional yang berkaitan dengan perbandingan antara masyarakat Sasak dan Samawa. Masyarakat Sasak yang digambarakan dalam cerita Batu Goloq memiliki kecenderungan untuk menyelesaikan masalah secara sendiri, sedangkan masyarakat Samawa dalam cerita Batu Plantolan lebih cenderung meminta bantuan kepada orang lain. Dua cara yang beroposisional ini merupakan sifat yang menunjukkan keterbukaan dan ketertutupan. Penyelesaian masalah secara sendiri dalam cerita Batu Goloq wujud perilaku perilaku tertutup, sedangkan penyelesaian masalah dengan meminta bantuan tokoh lain yang dilakukan dalam Batu Plantolan merupakan wujud perilaku terbuka

Perilaku tertutup dikatakan sebagai perilaku ketidakterbukaan terhadap orang luar, terutama pada orang yang dianggap asing. Jika merujuk cerita Batu Goloq, rangkaian awal digambarkan tentang kehidupan perekonomian tokoh yang kemudian mengarah pada permasalahan dan cara penyelesaian masalah. Gambaran awal mengenai kehidupan perekonomian menunjukkan bahwa hal tersebut merupakan latar belakang perilaku pada rangkaian peristiwa berikutnya. Apabila dilakukan pemadupadanan, maka perilaku tertutup dilatarbelakangi oleh kehidupan perekonomian, yakni kehidupan yang berada dalam kemiskinan. Kemiskinan akan memunculkan sikap tidak percaya diri, malu, dan selalu merasa kecil di tengah orang banyak. Berbeda dengan masyarakat Sasak, masyarakat Samawa yang 
digambarkan dalam cerita Batu Plantolan cenderung menyelesaikan permasalahan dengan meminta bantuan kepada orang lain. Cara penyelesaian masalah seperti ini memunculkan perilaku yang juga beroposisional dengan perilaku yang dimunculkan dari cara penyelesaian masalah secara sendiri. Jika masyarakat Sasak yang tergambar dalam Batu Goloq cenderung berperilaku tertutup, masyarakat Samawa yang tergambar dalam Batu Goloq lebih cenderung bersifat terbuka. Sama halnya dengan masyarakat Sasak dalam Batu Goloq, jika merujuk pada rangkaian awal cerita, sifat terbuka ini tidak bisa dilepaskan dari latar belakang kehidupan perekonomian tokoh sebagaimana digambarkan dalam Batu Plantolan. Kehidupan perekonomian pada taraf "berada" sebagaimana tokoh $i b u$ dalam Batu Plantolan, cenderung memunculkan sikap percaya diri sehingga tidak tidak ragu untuk meminta bantuan kepada orang lain, termasuk dalam menyelesaikan masalah yang dihadapi.

Cerita rakyat merupakan gambaran masyarakat pemiliknya. Gambaran yang terdapat pada cerita Batu Goloq dan Batu Plantolan bisa dikatakan merupakan gambaran masyarakat Sasak dan Samawa. Dengan demikian, oposisi cara penyelesaian masalah dengan latar belakang dan berbagai hal yang melingkupi bisa dikatakan sebagai gambaran oposisional masyarakat Sasak dan Samawa dalam cerita Batu Goloq dan Batu Plantolan. Oposisi biner berkaitan dengan cara penyelesaian masalah secara sendiri dan meminta bantuan orang lain sebagai wujud sikap keterbukaan dan ketertutupan merupakan gambaran watak masyarakat Sasak dan Samawa.

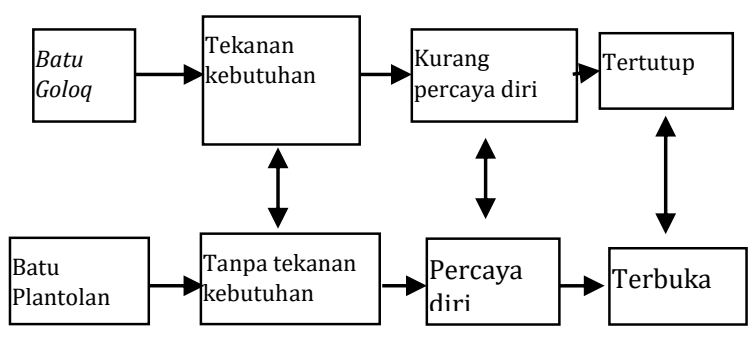

Kecenderungan masyarakat Sasak dengan ketertutupannya dan Samawa dengan keterbukaannya juga terlihat pada Mandalika dan Lala Buntar. Mandalika sebagai puteri raja cenderung menyelesaikan permasalahan sendiri tanpa mengikutsertakan tokoh lain. Mandalika berpikir sendiri dalam memilih keputusan yang akan diberikan berkaitan dengan lamaran pangeran/raja yang ingin mempersunting dirinya. Kesendirian itu terus terlihat sampai keputusan untuk membuang diri ke laut didapatkan. Mandalika tidak memberitahukan satu tokoh pun berkaitan dengan pilihan yang diambil, termasuk orang tua Dalam menjalankan keputusan yang telah ditetapkan itu pun tidak mengikutsertakan satu tokoh pun. 
Kondisi ketertutupan tersebut beroposisi dengan pola pengambilan keputusan yang dilakukan Lala Buntar. Tokoh itu langsung menyampaikan dan menceritakan keputusan yang diambil kepada orang tua maupun keluarganya. Proses pelaksanaan keputusan itu juga mengikutsertakan tokoh lain, yakni tokoh pengawal yang mengiringi dan menemani dalam perjalanan sampai terkubur dalam gundukan yang menjadi tempat persembunyiannya.
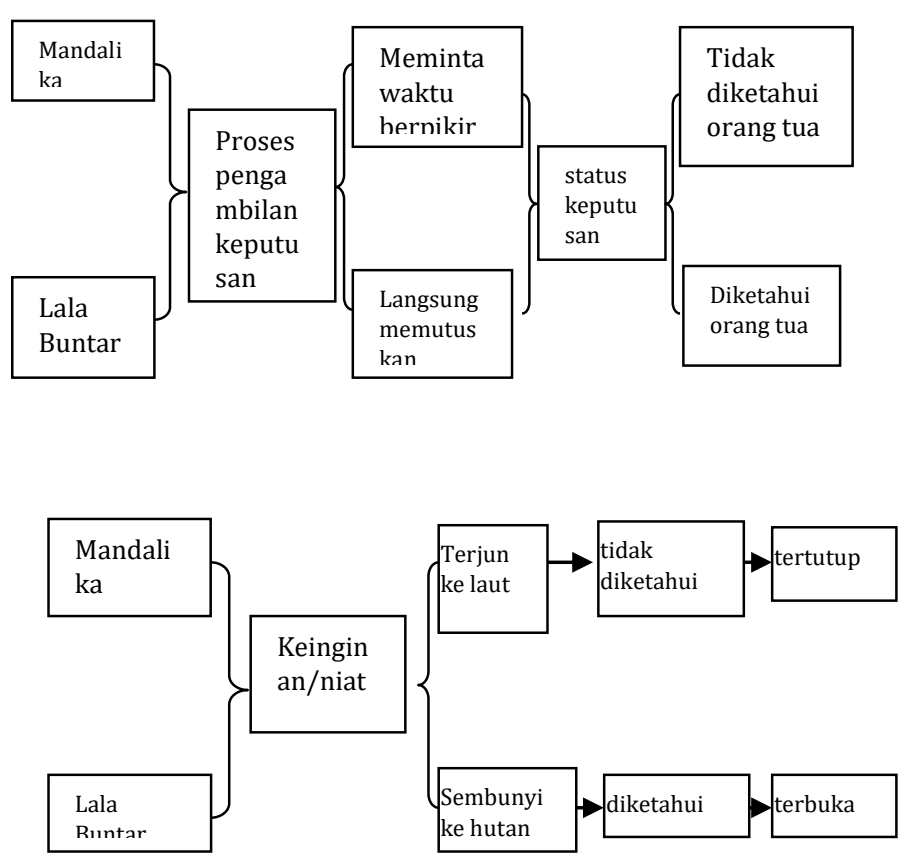

Keterbukaan dan ketertutupan dalam konteks masyarakat Sasak dan Samawa tidak bisa dilepaskan dari perbedaan latar belakang sejarah yang dijalani oleh kedua masyarakat tersebut. Latar belakang sejarah itu menjadikan masyarakat Sasak dan Samawa yang berasal dari satu nenek moyang dari segi bahasa (Mbete, 1990) tersebut menunjukkan perbedaan sikap dasar.

Adanya sifat dasar yang berbeda sebagaimana kita ketahui sekarang ini tidak bisa dilepaskan dari pengaruh perbedaan pola kolonialisasi yang telah terjadi pada etnis Sasak dan Samawa. Kolonialisasi etnis Sasak dilakukan oleh Karangasem Bali yang berasal dari barat, sedangkan etnis kolonialisasi etnis Samawa dilakukan etnis Bugis dari timur. Kolonialisasi yang dilakukan etnis Bali terhadap Sasak dan etnis Bugis terhadap Samawa memiliki tujuan dan pola yang berbeda. Mahsun (2006: 87) menjelaskan bahwa kolonialisasi yang dilakukan Karangasem Bali terhadap Sasak tidak hanya bermuatan politis, tetapi juga bermuatan kebudayaan. Muatan kebudayaan itu dilakukan dalam bentuk pemaksaan budaya dan adat-istiadat yang dimiliki dan dijalankan. Hal ini tentu berimplikasi pada penghilangan identitas. Kehilangan identitas menimbulkan keterasingan yang berakibat pada ketidakpercayaan diri dan pada tahap selanjutnya mengarah pada sifat ketertutupan.

Berbeda dengan kolonialisasi Karangasem Bali terhadap Sasak, kolonialisasi yang dilakukan Bugis terhadap Samawa yang oleh Mahsun (2006: 87) dikatakan lebih bermuatan religius ketimbang politis maupun kebudayaan. Kerajaan Bugis hanya meminta agar raja 
dan rakyat memeluk Islam, budaya dan adat istiadat yang tumbuh dan berkembang pada masyarakat Samawa dibiarkan berkembang. Pemaksaan untuk mengikuti adat istiadat dan budaya Bugis tidak dilakukan. Internalisasi budaya Bugis dalam budaya dan adat istiadat Samawa yang masih terlihat sampai saat ini dilakukan secara sukarela, tanpa paksaan sebagaimana yang dilakukan Bali terhadap Sasak.

Memberikan kesempatan tetap berkembangnya budaya dan adat istiadat masyarakat Samawa oleh Bugis menjadikan masyarakat Samawa tetap berada pada identitas yang dimiliki. Hal ini membawa implikasi pada kepercayaan diri yang pada tahap selanjutnya menumbuhkan sikap terbuka yang menjadikan masyarakat Samawa tidak canggung berinteraksi dengan masyarakat lain, termasuk meminta bantuan kepada orang lain sebagaimana yang dilakukan tokoh ibu dalam Batu Plantolan.

Keterbukaan masyarakat Samawa terhadap orang luar juga terlihat pada salah satu lawas yang cukup populer di tengahtengah masyarakat.

Mana tau barang kayu 'Walaupun orang itu bukan sanak keluarga

Lamen ya sanyaman ate 'Jika dia menenangkan hati atau membawa kedamaian`

Ba nansi sanak parana`Itulah saudara kita`
Lawas tersebut memberikan gambaran keterbukaan orang Samawa terhadap orang luar. Masyarakat Samawa mendefinisikan saudara bukan hanya orang yang berada dalam satu ikatan keluarga, tetapi juga semua orang yang berperilaku baik dan menenangkan. Tidak mengherankan jika di tengah-tengah lingkungan masyarakat Samawa di Sumbawa maupun Sumbawa Barat terdapat perkampungan-perkampungan masyarakat pendatang dengan nama kampung sesuai nama suku atau daerah asalnya, seperti Kampung Irian, Kampung Arab, dan lainlain.

Berbeda dengan dua pasangan cerita sebelumnya, konsep berpikir masyarakat Sasak dan Samawa pada padangan cerita Tegodek dait Tetuntel dan Ne Bote Ne Kakura menunjukkan adanya perlawanan masyarakat bawah terhadap masyarakat kelas atas. Kekonsistenan posisi yang ditunjukkan oleh tokoh monyet yang selalu berada pada posisi di atas menunjukkan bahwa tokoh ini merupakan keterwakilan dari masyarakat pada kelas sosial atas. Hal itu beroposisi dengan tokoh kodok maupun kurakura sebagai masyarakat kelas bawah yang ditandai dengan posisinya yang secara konsisten berada di bawah.

Gambaran protes kelas sosial bawah terhadap kelas sosial atas dalam kedua cerita terlihat dengan jelas ketika melihat 
keberadaan pohon pisang yang menjadi pusat permasalahan. Kehidupan nyata memperlihatkan bahwa pisang merupakan makanan yang sangat identik dengan monyet. Dikatakan demikian karena keberadaan pisang bagi monyet merupakan sebuah makanan sangat digemari. Hal yang menjadi permasalahan adalah ketidaktahuan monyet mengenai bagian pisang yang ditanam dan cara penanamannya. Sebagai tokoh yang memiliki makanan khas berupa pisang, tokoh monyet seharusnya mengetahui bagian dan cara penanaman pohon pisang tersebut. Sebaliknya, tokoh kura kura maupun tokoh katak yang tidak menjadikan pisang sebagai makanannya justru mengetahui bagian dan cara penanaman pisang sehingga pisang yang ditanamnya memiliki perkembangan yang sangat baik dibandingkan pisang yang ditanam monyet. Dua hal kontradiktif inilah yang dikatakan sebagai wujud protes masyarakat bawah terhadap masyarakat atas yang secara halus tertuang dalam cerita Tegodek dait Tetuntel maupun Ne Bote Ne Kakura.

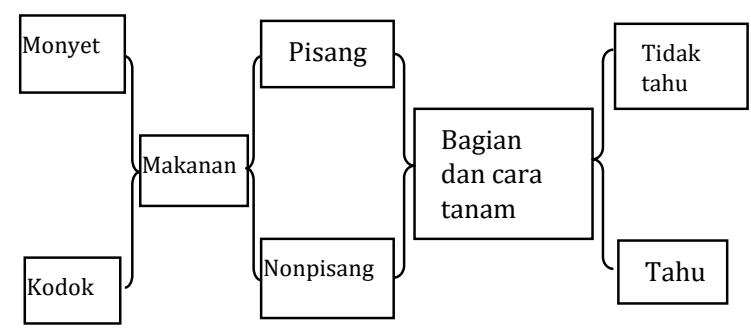

Protes masyarakat kalangan bawah terhadap masyarakat kalangan atas juga bisa dikatakan sebagai protes masyarakat atau rakyat terhadap pemimpinnya. Sebagaimana kita ketahui, Sasak dan Samawa termasuk dua suku yang pernah merasakan "dikuasai" oleh suku atau masyarakat lain. Sasak pernah merasakan penguasaan Karangasem Bali, sedangkan Samawa oleh Goa Sulawesi. Meskipun pola penguasaan kedua suku ini berbeda, tentu terdapat kesamaan terkait ketidakpuasan atau ketidakadilan perlakuan oleh masyarakat yang "menguasai" terhadap masyarakat yang "dikuasai”. Penyampaian ketidakpuasan atau ketidakadilan itu tidak bisa dilakukan dalam ruang publik sehingga dibutuhkan penyaluran alternatif dan cerita rakyat merupakan salah satu media penyaluran tersebut.

\section{Penutup}

Perbandingan cerita rakyat Samawa dan Sasak dilakukan dengan melihat persamaan dan perbedaan. Persamaan dan perbedaan tersebut berada pada beberapa bagian yang dikelompokkan menjadi miteme-miteme. Pengelompokkan ke dalam miteme-miteme menjadikan persamaan maupun perbedaan dari pasangan-pasangan cerita terlihat dengan jelas.

Perbandingan terhadap pasangan cerita memperlihatkan adanya perbedaan pola yang secara konsisten terlihat pada ketiga pasangan cerita. Pada pasangan cerita Batu 
Goloq dan Batu Plantolan terlihat adanya persamaan pada miteme "permasalahan yang dihadapi”, sedangkan perbedaan terlihat pada miteme "latar belakang kehidupan" dan "cara menyelesaikan masalah". Persamaan pada padangan cerita Mandalika dan Lala Buntar terlihat pada miteme "latar belakang tokoh" dan "permasalahan yang dihadapi", sedangkan perbedaannya terdapat pada miteme "cara menyelesaikan permasalahan”.

Pola persamaan dan perbedaan pada pasangan cerita Tegodek dait Tetuntel dengan Ne Bote Ne Kakura. Kedua cerita ini memiliki persamaan pada semua rangkaian cerita. Perbedaan terlihat pada peran tokoh protagonis yang menemani monyet sebagai tokoh antagonis. Tokoh katak merupakan tokoh protagonis dalam Tegodek dait Tetuntel, sedangkan tokoh kurakura sebagai tokoh protagonis dalam Ne Bote Ne Kakura.

Perbandingan dengan melihat persamaan dan perbedaan tersebut menunjukkan adanya pola yang konsisten dalam menyelesaikan masalah. Pola yang konsisten tersebut menunjukkan adanya kecenderungan ketertutupan pada masyarakat Sasak yang beroposisi dan keterbukaan pada masyarakat Samawa. Keterbukaan dan ketertutupan itu tidak bisa dilepaskan dari perbedaan latar belakang sejarah berupa perbedaan pola kolonialisasi yang dialami oleh kedua masyarakat tersebut.

\section{Daftar Pustaka}

Ahimsa-Putra, Heddy Shri. (2003). "Dari Antropologi Budaya ke Sastra dan Sebaliknya" dalam Sastra Interdisipliner: Menyandingkan Sastra dan Disiplin Ilmu Sosial Lainnya. Sirojuddin Arif (penyunting). Yogyakarta: Qalam.

Ahimsa-Putra, Heddy Shri. (2013). Strukturalisme Levi-Strauss: Mitos dan Karya Sastra. Yogyakarta: Kepel Press.

Bahri, Syaiful dkk. (2015). "Relasi Kekerabatan Sastra Sasak dan Samawa di Pulau Lombok dan Sumbawa" (Laporan Penelitian). Mataram: Kantor Bahasa NTB.

Bahri, Syaiful. (2014). "Analisis Struktural Fabel Tegodek dait Tetuntel: Representasi Perilaku dalam Masyarakat Sasak. Jurnal Mabasan Volume 8 Nomor 2 Juli-Desember 2014. Mataram: Kantor Bahasa Provinsi NTB.

Burhanuddin. (2010). "Sejarah Komunitas Sumbawa di Pulau Lombok: Suatu Telaah Perspektif Linguistik". Mataram: Universitas Mataram.

Damono, Sapardi Djoko. (2009). Sastra Bandingan. Jakarta: Editum.

Danandjaja, James. (2002). Folklor Indonesia: Ilmu Gosip, Dongeng, dan Lain-Lain. Jakarta: Pustaka Utama Grafiti.

Endraswara, Suwardi. (2009). Metode Penelitian Folklor: Konsep, Teori, dan 
Aplikasi. Yogyakarta: Media Pressindo.

Endraswara, Suwardi. (2011). Sastra Bandingan: Pendekatan dan Teori Pengkajian. Yogyakarta: Lumbung Ilmu.

Eriyanto. (2013). Analisis Naratif: Dasardasar dan Penerapannya dalam Analisis Teks Berita Media. Jakarta: Kencana.

Mahsun, (2006). Bahasa dan Relasi Sosial: Telaah Kesepadanan Adaptasi Linguistik dengan Adaptasi Sosial. Yogyakarta: Gama Media.

Mantja, Lalu. (2011). Sumbawa pada Masa Dulu (Suatu Tinjauan Sejarah). Sumbawa Besar: Samratulangi.

Mbete, Aron Meko. (1990). "Rekonstruksi Protobahasa Bali-Sasak-Sumbawa" (Disertasi). Jakarta: Universitas Indonesia.

Ratna, Nyoman Kutha. (2009). Teori, Metode, dan Teknik Penelitian Sastra. Yogyakarta: Pustaka Pelajar.

Rokhman, Muh. Arif. (2003). "Pendahuluan: dari Monodisipliner menuju Interdisipliner" dalam Sastra Interdisipliner: Menyandingkan Sastra dengan Disiplin Ilmu Sosial. Sirojuddin Arif (penyunting). Yogyakarta: Qalam.Safarudin, Balok. 2011. Kumpulan Cerita Rakyat Sasak. Pringgabaya: CV Gumi Sasak.

Sugiyono. (2008). Metode Penelitian Kuantitatif Kualitatif dan $R \& D$. Bandung: Alfabeta.

Taum, Yoseph Yapi. (2011). Studi Sastra Lisan: Sejarah, Teori, Metode, dan Pendekatan Disertai Contoh Penerapannya. Yogyakarta: Lamalera.
Wacana, Lalu. (1988). Sejarah Daerah Nusa Tenggara Barat. Jakarta: Depdikbud. 